\title{
Vertical transmission of HIV: a prospective study
}

\author{
J Y Q MOK, ${ }^{*}$ R A HAGUE,${ }^{*} P$ L YAP, $\dagger F$ D HARGREAVES,$\ddagger J$ M INGLIS, $\ddagger J$ M WHITELAW,$\S$

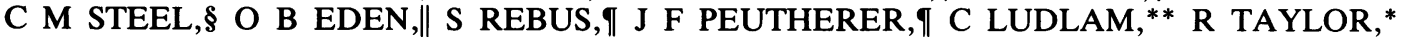 \\ L R MACCALLUM,* AND R P BRETTLE*
}

*Infectious Diseases Unit, City Hospital; †Scottish National Blood Transfusion Service; $\ddagger$ Regional Virus Laboratory; \$MRC Population and Cytogenetics Unit; |Haematology Department, Royal Hospital for Sick Children; $\left\lceil\right.$ Department of Virology, University of Edinburgh; and ${ }^{* *}$ Haematology Department, Royal Infirmary, Edinburgh

SUMMARY Forty nine infants of HIV seropositive women were followed up for a median of 24 months, together with 24 controls. The infection status of 11 index children under 18 months of age was indeterminate; 34 were presumed uninfected while four showed clinical and laboratory evidence of HIV disease. Based on current definitions of HIV infection and excluding children under 18 months old as well as those who had not been studied from birth, two out of 28 children were infected. The estimated rate of maternofetal transmission was therefore $7 \cdot 1 \%$. In children with proved infection, sequential laboratory data showed that hypergammaglobulinaemia was noted as early as 6 months and often predated clinical signs. This observation, in the presence of non-specific clinical findings, was helpful in alerting the paediatrician to a diagnosis of HIV infection.

Vertical transmission of the human immunodeficiency virus (HIV) is now well documented, ${ }^{1-3}$ although the exact risk has not yet been quantified. Rates of transmission appear to vary from $22-65 \%$, depending on inclusion criteria and duration of the study as well as methods used to define paediatric HIV infection..$^{4-6}$ The diagnostic value of an HIV antibody test is limited by the presence of passively acquired maternal antibody in infants. Clinical evidence of infection is also unreliable, especially in the early stages when signs and symptoms are nonspecific. ${ }^{7}$ The inclusion of control children is therefore essential, in order that clinical and laboratory parameters can be evaluated. So far, no study of mother to child transmission of HIV has included a control group.

In the United Kingdom, Edinburgh has been reported to have the largest population of intravenous drug users infected with HIV, one third of whom are young women. ${ }^{8}$ Most were infected during an epidemic of needle sharing in 1983-4, and most are asymptomatic at present. Centres which reported high rates of vertical transmission of HIV had initially concentrated on women who had more advanced disease. We postulated that the same risk might not apply when the mother had preclinical disease. Infants born to HIV seropositive women were therefore enrolled into a prospective study to evaluate the risk of maternofetal transmission and to define the natural history of perinatally acquired HIV disease in those who were infected.

\section{Subjects and methods}

SUBJECT SELECTION

The paediatric counselling and screening clinic at the City Hospital in Edinburgh was established in January 1986 to monitor all infants born to HIV seropositive women. Edinburgh is one of the centres collaborating in the European Multicentre Study on perinatal transmission of HIV.

Most HIV infected pregnant women were identified in the antenatal period. If the woman chose to continue with her pregnancy, permission was sought for inclusion of her infant in the study. Thirty nine infants were thus enrolled, together with 10 who were referred either subsequent to the mother's HIV antibody test being positive, or because of symptoms suggesting HIV disease. These 49 infants comprised the index group.

Twenty four infants born to HIV seropositive fathers but whose mothers remained seronegative were included as controls. Mothers were tested after self identification of high risk activities, and belonged 
to similar socioeconomic groups as mothers who tested positive.

PROCEDURE AT FOLLOW UP

The procedure at follow up was identical for children in both index and control groups. Those infants identified antenatally were seen and examined at birth, at age 6 weeks, and 3 months, and at intervals of three months until the age of 2 . Thereafter review occurred every six months if the child remained well. Others were seen according to the protocol from the time of referral.

At each visit, a history was taken according to a standard questionnaire and the child examined for symptoms and signs of HIV disease. Developmental screening was performed using the Denver developmental screening test. Length, weight, and head circumference were documented. Blood was then taken for laboratory tests.

\section{LABORATORY METHODS}

At intervals of three months HIV antibody was measured in both index and control children using an antiglobulin enzyme immunoassay (Abbott Recombinant HIV 1 ETA) followed by a competitive enzyme immunoassay (Wellcozyme). For index children, HIV 1 antigen was measured by quantified enzyme immunoassay (Abbott HTLV 3 antigen EIA). Lymphocytes were cultured for HIV every six months in all index children; positive results were confirmed by antigen capture.

Other investigations on peripheral blood included measurement of haemoglobin, total white cell and differential count, T lymphocyte subsets, platelet count, and immunoglobulin concentrations as previously described. ${ }^{4} 5$

The significance of various comparisons were tested using the $\chi^{2}$ test, or Student's $t$ test as appropriate.

\section{Results}

\section{MATERNAL DATA}

Characteristics of mothers of index and control children are shown in table 1 . All were white. Thirty seven index mothers were infected through intravenous drug use and six were heterosexual contacts. No differences were seen between the two groups of women in the use of drugs during pregnancy, although more index mothers resorted to drug use after the birth of the child. No woman had AIDS or AIDS related illnesses before the delivery of the child, although one developed Pneumocystis carinii pneumonia during a third pregnancy that was terminated at 18 weeks' gestation. The remaining 42 index mothers were clinically free of HIV related
Table 1 Characteristics of 43 index and 24 control mothers

\begin{tabular}{|c|c|c|}
\hline & $\begin{array}{l}\text { Index } \\
\text { No (\%) }\end{array}$ & $\begin{array}{l}\text { Control } \\
\text { No }(\%)\end{array}$ \\
\hline Mean age at delivery (years) & $24 \cdot 1$ & $23 \cdot 6$ \\
\hline Single mother & $15(31)$ & $5(21)$ \\
\hline First born child & 21 (43) & $11(45)$ \\
\hline Drug use during pregnancy & 14 (29) & $2(8)$ \\
\hline Drug use since pregnancy & $20(41)$ & $2(8)^{*}$ \\
\hline Infant in alternative care & $12(24)$ & $1(4)$ \\
\hline
\end{tabular}

${ }^{*} \mathrm{p}<0.05\left(\chi^{2}\right.$ test $)$.

symptoms. There were two sets of twins and four sibling pairs among the index children.

\section{INFECTION STATUS OF INDEX CHILDREN}

Four index children showed clinical evidence of HIV disease (table 2), two of whom were referred because of symptoms. All had positive cultures for HIV, with HIV antigenaemia and persistence of HIV antibody beyond 18 months of age. These children were definitely infected.

Of the remaining cohort, 11 were under 18 months of age and because of presence of maternal antibody, were classified as indeterminate status. ${ }^{7}$ None had positive results for HIV antigen or culture. Of 38 index children over the age of 18 months, 34 were HIV antibody negative, HIV antigen as well as culture negative. They were clinically free of symptoms that suggest HIV disease and have normal tests of immune function. These 34 children were presumed uninfected.

\section{PERINATAL DATA}

Table 3 summarises perinatal data of index and control children, with the index cohort separated into children who were infected and those presumed uninfected. The mean birth weight was significantly lower in index children presumed uninfected $(95 \%$ confidence interval (CI) 2714 to $3078 \mathrm{~g}$ ) when compared with controls, (95\% CI 3069 to $3527 \mathrm{~g}$ ) and the difference remained when all children whose mothers used drugs during pregnancy were excluded from analysis. The effect of preterm delivery was allowed for by extrapolating preterm birth weight to term, along the same centile, and index children presumed uninfected were significantly lighter than controls.

All but one index infant were delivered by spontaneous vaginal delivery. Neonatal special care was required mainly for drug withdrawal symptoms and intrauterine growth retardation. Intensive care was only necessary for two index infants because of problems arising from preterm delivery. These consisted of meningitis with septicaemia resulting in ventriculoperitoneal shunts for hydrocephalus 
1142 Mok, Hague, Yap, et al

Table 2 Clinical and laboratory evidence of HIV infection in four children

\begin{tabular}{|c|c|c|c|c|c|c|c|c|}
\hline Sex & $\begin{array}{l}\text { Birth } \\
\text { weight } \\
\text { (g) }\end{array}$ & $\begin{array}{l}\text { Gestation } \\
\text { (weeks) }\end{array}$ & $\begin{array}{l}\text { Symptoms/signs } \\
\text { (age in months } \\
\text { when first } \\
\text { appeared) }\end{array}$ & & $\begin{array}{l}\text { Lowest } \\
\text { absolute } \\
\text { T4 count } \\
\left(\times 10^{9} / l\right)\end{array}$ & $\begin{array}{l}\text { Lowest } \\
\text { platelet } \\
\text { count } \\
\left(\times 10^{9} / l\right)\end{array}$ & $\begin{array}{l}\text { Highest } \\
\lg G \\
(g / l)\end{array}$ & $\begin{array}{l}\text { Outcome } \\
\text { (age at } \\
\text { last review) }\end{array}$ \\
\hline $\mathbf{F}$ & 3273 & 42 & $\begin{array}{l}\text { Lymphadenopathy } \\
\text { Respiratory infections } \\
\text { Hepatomegaly } \\
\text { Failure to thrive } \\
\text { Interstitial pneumonia } \\
\text { Diarrhoea } \\
\text { Eczema }\end{array}$ & $\begin{array}{l}(6) \\
(6) \\
(6) \\
(6) \\
(9) \\
(9) \\
(12)\end{array}$ & $0 \cdot 16$ & 79 & $16 \cdot 0$ & $\begin{array}{l}\text { On intravenous } \\
\text { IgG and zidovudine } \\
\text { ( } 34 \text { months) }\end{array}$ \\
\hline $\mathbf{M}$ & 930 & 29 & $\begin{array}{l}\text { Recurrent cough } \\
\text { Purpura } \\
\text { Lymphadenopathy } \\
\text { Hepatosplenomegaly } \\
\text { Night sweats } \\
\text { Parotitis }\end{array}$ & $\begin{array}{r}(8) \\
(9) \\
(14) \\
(14) \\
(30) \\
(44)\end{array}$ & 0.55 & 14 & $24 \cdot 0$ & $\begin{array}{l}\text { On intravenous } \\
\text { IgG (50 months) }\end{array}$ \\
\hline $\mathbf{F}$ & 3320 & 38 & $\begin{array}{l}\text { Respiratory infections } \\
\text { Diarrhoea } \\
\text { Lymphadenopathy } \\
\text { Recurrent fever } \\
\text { Hepatosplenomegaly } \\
\text { Pneumonia } \\
\text { Purpura } \\
\text { Dry skin } \\
\text { Molluscum }\end{array}$ & $\begin{array}{l}(6) \\
(6) \\
(10) \\
(10) \\
(10) \\
(12) \\
(34) \\
(36) \\
(42)\end{array}$ & 0.05 & 50 & $20 \cdot 8$ & $\begin{array}{l}\text { On intravenous } \\
\text { IgG and zidovudine } \\
\text { ( } 46 \text { months) }\end{array}$ \\
\hline$F$ & 2180 & 37 & $\begin{array}{l}\text { Respiratory infections } \\
\text { Diarrhoea } \\
\text { Lymphadenopathy } \\
\text { Eczema } \\
\text { Hepatosplenomegaly }\end{array}$ & $\begin{array}{r}(3) \\
(3) \\
(6) \\
(15) \\
(15)\end{array}$ & 1.0 & 19 & $23 \cdot 2$ & $\begin{array}{l}\text { On intravenous } \\
\text { IgG ( } 25 \text { months })\end{array}$ \\
\hline
\end{tabular}

Table 3 Perinatal data of 38 index and 24 control children

\begin{tabular}{|c|c|c|c|}
\hline & \multicolumn{2}{|l|}{ Index } & \multirow{2}{*}{$\begin{array}{l}\text { Control } \\
(n=24)\end{array}$} \\
\hline & $\begin{array}{l}\text { Infected } \\
(n=4)\end{array}$ & $\begin{array}{l}\text { Presumed } \\
\text { uninfected } \\
(n=34)\end{array}$ & \\
\hline Boys & 1 & 18 & 15 \\
\hline No with delivery $<37$ weeks' gestation & 1 & 6 & 2 \\
\hline No with birth weight $<10$ th centile & 1 & 9 & 2 \\
\hline No who had neonatal special care & 3 & 7 & 3 \\
\hline Mean birth weight $(\mathrm{g})$ & 2426 & $2896^{*}$ & $3298^{*}$ \\
\hline $\begin{array}{l}\text { Mean birth weight (g) } \\
\text { (excluding children whose } \\
\text { mothers used drugs during } \\
\text { pregnancy) }\end{array}$ & 3296 & $3027^{*}$ & $3378^{*}$ \\
\hline \multicolumn{4}{|c|}{$\begin{array}{l}\text { "p<0.02 (Student's unpaired } t \text { test). Other comparisons, between index and control as well as within index children. did not react } \\
\text { significance. }\end{array}$} \\
\hline \multicolumn{2}{|c|}{$\begin{array}{l}\text { and necrotising enterocolitis necessitating laparo- } \\
\text { tomy. Cystic fibrosis was diagnosed in one index } \\
\text { infant while another had multiple intracardiac } \\
\text { tumours. No infant received a blood transfusion in } \\
\text { the neonatal period, and there were no neonatal } \\
\text { deaths. The features of HIV embryopathy were not }\end{array}$} & \multicolumn{2}{|c|}{$\begin{array}{l}\text { observed in any infant. }{ }^{9} \text { Although hepatospleno- } \\
\text { megaly was documented during the neonatal period } \\
\text { in two index infants, this did not persist beyond } \\
\text { three months. Two index infants were breast fed } \\
\text { (for five and } 36 \text { weeks each) but none from the } \\
\text { control group. }\end{array}$} \\
\hline
\end{tabular}


CLINICAL OUTCOME

The median age when last seen was 24 months for index infants (range 3 to 52 months), 12 months for controls (range 3 to 30 months). No child has been lost to follow up. Within the index group, children whose infection status was indeterminate have been excluded from analysis. Signs and symptoms observed in index and control children are shown in table 4 , with index children separated into those infected and presumed uninfected.

Appreciable lymphadenopathy was defined as the presence of nodes $>0.5 \mathrm{~cm}$ in diameter in more than two non-contiguous sites (excluding inguinal) and persisting beyond three months. Chronic or recurrent respiratory infections were those which occurred on three or more occasions within a three month period. Recurrent diarrhoea was defined as loose stools that persisted beyond 48 hours, required treatment, and occurred on more than one occasion per month.

Failure to thrive was diagnosed when the child's sequential weights declined across centile lines.

As seen in table 4, signs and symptoms were nonspecific and were seen in control as well as index children. Lymphadenopathy and recurrent respira- tory infections were seen in appreciably more index children, even those presumed uninfected, when compared with controls. All index children presumed uninfected had symptoms and signs which resolved with time; they never had positive HIV antigen or culture results.

Neurological signs were detected only in the child with neonatal meningitis (ataxic diplegia). The developmental progress of the remaining cohort was within normal limits.

\section{LABORATORY RESULTS}

Laboratory abnormalities are shown in table 5. No significant differences were seen when the index children were compared with controls. Within the index children, however, those presumed uninfected were significantly less likely to have persistent hypergammaglobulinaemia, lymphopenia, T4 lymphopenia, and thrombocytopenia. Abnormal laboratory results in index children presumed uninfected tended to be transient findings which returned to the normal range on repeat testing.

Sequential laboratory data within the index group are displayed in table 6 . Hypergammaglobulinaemia was noted as early as 6 months, and often predated

Table 4 Clinical signs and symptoms in 38 index and 24 control children

\begin{tabular}{|c|c|c|c|}
\hline & \multicolumn{2}{|l|}{ Index } & \multirow{2}{*}{$\begin{array}{l}\text { Control } \\
(n=24)\end{array}$} \\
\hline & $\begin{array}{l}\text { Infected } \\
(n=4)\end{array}$ & $\begin{array}{l}\text { Presumed } \\
\text { uninfected } \\
(n=34)\end{array}$ & \\
\hline Significant lymphadenopathy & $4^{*}$ & $9^{*}$ & $0^{*}$ \\
\hline Recurrent respiratory infections & 4 & $13^{*}$ & $2^{*}$ \\
\hline Recurrent diarrhoca & $4^{*}$ & $11^{*}$ & 5 \\
\hline Eczematous rash & 3 & 7 & 1 \\
\hline Hepatosplenomegaly & $4^{*}$ & $4^{*}$ & 0 \\
\hline Failure to thrive & 1 & 3 & 0 \\
\hline
\end{tabular}

${ }^{*} p<0 \cdot 05\left(\chi^{2}\right.$ test $)$. Other comparisons between index and control children, as well as within index children, did not reach significance.

Table 5 Laboratory abnormalities in 38 index and 24 control infants

\begin{tabular}{llll}
\hline & \begin{tabular}{l} 
Index \\
\cline { 2 - 4 }
\end{tabular} & $\begin{array}{l}\text { Infected } \\
(n=4)\end{array}$ & $\begin{array}{l}\text { Control } \\
(n=24)\end{array}$ \\
\hline Hypogammaglobulinacmia & & $\begin{array}{l}\text { Presumed } \\
\text { uninfected } \\
(n=34)\end{array}$ & \\
Hypergammaglobulinacmia & 0 & 13 & 4 \\
Neutropenia $\left(<1 \cdot\left(0 \times 10^{4} / 1\right)\right.$ & $4^{*}$ & $4^{*}$ & 3 \\
Lymphopenia $\left(<2 \cdot 8 \times 10^{9} / 1\right)$ & 1 & 2 & 2 \\
T4 lymphopenia $\left(<1 \cdot\left(0 \times 10^{4} / 1\right)\right.$ & $3^{*}$ & $4^{*}$ & 1 \\
T4/T8<1.0 & $3^{*}$ & $0^{*}$ & 1 \\
Thrombocytopenia $\left(<100 \times 10^{*} / 1\right)$ & $4^{*}$ & $4^{*}$ & 0 \\
\hline
\end{tabular}

${ }^{*} \mathrm{p}<0.05\left(\chi^{2}\right.$ test $)$. 
Table 6 Sequential laboratory results on index children over 18 months old

\begin{tabular}{|c|c|c|c|c|c|c|c|c|c|c|}
\hline & \multicolumn{2}{|c|}{3 Months } & \multicolumn{2}{|c|}{6 Months } & \multicolumn{2}{|c|}{ 9-12 Months } & \multicolumn{2}{|c|}{ 15-18 Months } & \multicolumn{2}{|c|}{ 21-24 Months } \\
\hline & $\begin{array}{l}\text { Infected } \\
(n=2)\end{array}$ & $\begin{array}{l}\text { Presumed } \\
\text { uninfected } \\
(n=33)\end{array}$ & $\begin{array}{l}\text { Infected } \\
(n=2)\end{array}$ & $\begin{array}{l}\text { Presumed } \\
\text { uninfected } \\
(n=25)\end{array}$ & $\begin{array}{l}\text { Infected } \\
(n=2)\end{array}$ & $\begin{array}{l}\text { Presu } \\
\text { uninfe } \\
(n=32\end{array}$ & $\begin{array}{l}\text { Infected } \\
(n=3)\end{array}$ & $\begin{array}{l}\text { Presum } \\
\text { uninfec } \\
(n=29)\end{array}$ & $\begin{array}{l}\text { Infected } \\
(n=3)\end{array}$ & $\begin{array}{l}\text { Presumed } \\
\text { uninfected } \\
(n=24)\end{array}$ \\
\hline \multirow{6}{*}{$\begin{array}{l}\text { IgG }(g / l) \\
\text { IgA }(g / l) \\
\text { IgM }(g / l) \\
\text { Lymphocytes }\left(\times 10^{9} / 1\right) \\
\text { T4 lymphocytes }\left(\times 10^{9} / 1\right) \\
\text { Platelets }\left(\times 10^{9} / l\right)\end{array}$} & $5 \cdot 20$ & 3.66 & $10 \cdot 30$ & $4 \cdot 08$ & $12 \cdot 70$ & $5 \cdot 59$ & $14 \cdot 63$ & $7 \cdot 08^{*}$ & $13 \cdot 7$ & $7 \cdot 78$ \\
\hline & 0.65 & 0.34 & 1.40 & 0.47 & 1.50 & 0.78 & 1.48 & $0 \cdot 80$ & $1 \cdot 17$ & 0.79 \\
\hline & $1 \cdot 10$ & 0.75 & $1 \cdot 28$ & 0.81 & $1 \cdot 12$ & 1.05 & $1 \cdot 13$ & $1 \cdot 11$ & $1 \cdot 32$ & $1 \cdot 16$ \\
\hline & 8.20 & $8 \cdot 10$ & $8 \cdot 82$ & 7.90 & $10 \cdot 08$ & $6 \cdot 57$ & $4 \cdot 81$ & $6 \cdot 78$ & 6.05 & $5 \cdot 21$ \\
\hline & \multicolumn{2}{|c|}{ ND } & \multicolumn{2}{|c|}{ ND } & \multicolumn{2}{|c|}{ ND } & 0.82 & $2 \cdot 54^{*}$ & 1.59 & $2 \cdot 18$ \\
\hline & 397 & 376 & 262 & 362 & 294 & 305 & 145 & $336^{*}$ & 52 & $367^{*}$ \\
\hline
\end{tabular}

The data represent mean values at each follow up interval. $\mathrm{ND}=$ Not done.

${ }^{*} \mathrm{p}<0.05$ Student's unpaired $t$ test.

clinical signs. Significance was not reached until 15-18 months of age. With progression of clinical disease, other useful laboratory markers were T4 lymphopenia and thrombocytopenia.

LOSS OF MATERNAL HIV ANTIBODY

No child in the control group was HIV antibody positive at any time.

Of index infants, maternal HIV antibody was lost from 6-18 months, median 12 . Thirty four children over 18 months of age remained antibody negative. They were also HIV antigen as well as culture negative. The follow up of these children from the time of seroreversion ranged from 3 to 33 months (median 18). Subsequent seroconversion after seroreversion has not been observed in the cohort.

\section{RATE OF MATERNOFETAL TRANSMISSION}

To calculate a transmission rate of HIV from mother to child, those children aged less than 18 months $(n=11)$ as well as those not monitored from birth $(n=10)$ have been excluded. Of the 28 remaining children, two showed clinical and laboratory vidence of HIV disease while 26 were presumed not to be infected. The estimated vertical transmission rate was therefore $7 \cdot 1 \%$. (95\% CI 0 to $16 \cdot 6 \%)$.

\section{Discussion}

Initial reports of paediatric AIDS concentrated on children who presented with end stage disease, ${ }^{10-12}$ and they are not typical of the entire clinical range of HIV infected children. Increasing awareness and experience of children at risk of AIDS have allowed an improved classification of signs and symptoms observed in paediatric HIV infection. ${ }^{7}$ The children in our study with proved HIV infection had common, non-specific clinical findings which might have been managed differently had they presented in another setting. The laboratory abnormalities that we observed were not exclusive to the infected children, and this again underlines the importance of regular follow up with sequential data and the inclusion of control children.

Most index mothers were infected through needle sharing during intravenous drug use. As most of these women come from areas of multiple deprivation, this is likely to adversely affect their infant's health and development. A previous study from Edinburgh of women who identified themselves as being at risk of HIV infection showed no significant differences in social characteristics of those who subsequently tested HIV positive, compared with HIV negative women. ${ }^{13}$ Rather, similarities were seen in infant morbidity (low birth weight, intrauterine growth retardation, preterm delivery) in both groups of women, which were increased three fold when compared with the general population. Our choice of control infants was such that both groups were comparable in social and epidemiological factors, as well as maternal intravenous drug use during pregnancy. Despite that, the mean birth weight of the index infants presumed uninfected was significantly lower than that of controls, allowing for maternal drug use and prematurity. This could be a direct effect of HIV during pregnancy.

In estimating the vertical transmission rate, we had excluded children under 18 months of age, although the current recommendation is that children aged over 15 months who test antibody positive are defined as infected. ${ }^{7}$ Our experience is that maternal antibody can persist until 18 months of age, and had we defined three such children as infected, we would have overestimated the prevalence of infection. Children referred because of HIV related symptoms would also add to an overestimate of infection. Therefore in the calculation of infection risk, only children monitored prospectively from birth were included. The risk of vertical 
transmission, as estimated from our data, was $7 \cdot 1 \%$, lower than that previously reported. ${ }^{4-6}$ This could be explained, in part, by the fact that all the infected women were free of HIV related symptoms during pregnancy. Testing for HIV antigen was performed in eight mothers during pregnancy, and in 22 after delivery of the infant-all were found to be negative. Our results must be interpreted with caution, as the numbers are small and as yet, the prognosis for children aged over 18 months who lose maternal antibody is unknown. Although not observed in our cohort, children have been reported to lose antibody only to seroconvert later on in childhood, ${ }^{14}$ while others have been documented to remain antibody negative with positive antigen tests and virus culture. $^{4} 515$

Recent developments in diagnostic techniques, such as in vitro production of HIV specific antibody, ${ }^{16}$ or polymerase chain reactions for amplification of viral DNA,${ }^{17}$ are still under evaluation and not routinely available. A recent study found that six of 14 asymptomatic newborns, and five of 10 seronegative children of infected mothers were positive for HIV-DNA, using the polymerase chain reaction technique. ${ }^{18}$ Using more sophisticated tests, the numbers of infected children in our cohort could be higher. There is, however, an urgent need for improved methods to evaluate the seronegative index children who remain clinically well with normal immune function, as four mothers have embarked on subsequent pregnancies based purely on the observation that the index child was symptom free and antibody negative (presumed uninfected).

We were unable to detect any laboratory predictor of HIV disease when sequential index and control data were compared. In the children with proved infection, immunoglobulin concentrations (especially IgG) did, however, start to rise before clinical signs were obvious. Clinical manifestations are non-specific, but when seen in conjunction with laboratory abnormalities (hypergammaglobulinaemia, T4 lymphopenia, thrombocytopenia), a diagnosis of HIV infection can be strongly suspected in a child especially when mother has engaged in high risk activities.

In future, we hope to use the polymerase chain reaction to detect HIV-DNA in the index children presumed uninfected. It must be stressed that the demonstration of viral DNA sequences does not imply overt infection, as little is known about the immune response to HIV in children infected antenatally. Our study stresses the importance of zontinued careful follow up of all children at risk of HIV infection, to detect early markers of infection as well as to determine the outcome of those who uppear symptom free.
The study is supported by the Medical Research Council, the Scottish National Blood Transfusion Service, and the AIDS Virus Education and Research Trust. We are grateful to Lesley Boyd for typing the manuscript. We thank Dr D J Jeffries and the staff at the virology department, St Mary's Hospital, London for initiating HIV cultures on the cohort; the laboratory staff at the haematology department, Royal Hospital for Sick Children, Edinburgh for their cooperation; and staff in Wards 7a and 15 at the City Hospital for their help.

\section{References}

1 Sprecher S, Soumenkoff G, Puissant F, Degueldre M. Vertical transmission of HIV in 15 week fetus. Lancet 1986;ii:288-9.

2 Lapointe N, Michaud J, Pekovic D, Chausseau JP, Dupuy JM. Transplacental transmission of HTLV III virus. $N$ Engl $J$ Med 1985:312:1325-6.

3 Jovaisas E, Koch MA, Schafer A, Stauber M, Lowenthal D. LAV/HTLV III in 20 week fetus. Lancet 1985;ii:1129.

4 Mok JQ, Giaquinto C, de Rossi A, Grosch-Worner I, Ades AE, Peckham CS. Infants born to mothers seropositive for human immunodeficiency virus. Lancet 1987;i:1164-8.

5 The European Collaborative Study. Mother-to-child transmission of HIV infection. Lancet 1988;ii:1039-42.

${ }^{6}$ Minkoff H, Nanda D, Meneg R, Fikrig S. Pregnancies resulting in infants with acquired immunodeficiency syndrome or AIDS related complex: follow-up of mothers, children and subsequent siblings. Obstet Gynecol 1987;69:288-91.

7 Centers for Disease Control. Classification system for human immunodeficiency infection in children under 13 years of age. MMWR 1987;36:225-35.

${ }^{8}$ Brettle RP, Bisset K. Burns S, et al. Human immunodeficiency virus and drug misuse; the Edinburgh experience. $\mathrm{Br}$ Med $\mathrm{J}$ 1987:295:421-4.

${ }^{9}$ Marion RW, Wiznia AA, Hutcheon RG, Rubenstein A. Human T-cell lymphotropic virus type III (HTLV III) embryopathy. Am J Dis Child 1986;140:638-40.

10 Oleske J, Minnefor A, Cooper R, et al. Immune deficiency syndrome in children. JAMA 1983;249:2345-9.

$"$ Rubenstein A, Sicklick M, Gupta A, et al. Acquired immunodeficiency with reversed T4/T8 ratios in infants born to promiscuous and drug addicted mothers. JAMA 1983;249: $2350-6$.

12 Scott GB, Buck BE, Leterman JG. Acquired immunodeficiency syndrome in infants. $N$ Engl $J$ Med 1984:310:76-81.

13 Johnstone FD, MacCallum L, Brettle RP. Inglis JM. Peutherer JF. Does infection with HIV affect the outcome of pregnancy? Br Med J 1988;296:467.

14 Aiuti F, Luzi G, Mezzaroma I, Scano G, Papetti C. Delayed appearance of HIV infection in children. Lancet 1987;ii:858.

15 Borkowsky W, Krasinski K, Paul D, Moore T, Bebenroth D, Chandwani S. Human immunodeficiency virus infection in infants negative for anti-HIV by enzyme linked immunoassay. Lancet 1987;i:1168-71.

16 Amadori A, deRossi A, Giaquinto C. Faulkner-Valle G, Zacchello $F$, Chicco-Bianchi L. In vitro production of HIVspecific antibody in children at risk of AIDS. Lancet 1988;i: $852-4$

17 Ou CY, Kwok S, Mitchell SW, et al. DNA amplication for direct detection of HTV-1 in DNA of peripheral blood mononuclear cells. Science 1988;239:295-7.

18 Laure F, Rouzioux C, Veber F, et al. Detection of HIV-1 DNA in infants and children by means of the polymerase chain reaction. Lancet 1988;ii:538-41.

Correspondence to Dr JYQ Mok, Infectious Diseases Unit, City Hospital. Greenbank Drive, Edinburgh EH10 5SB.

Accepted 11 April 1989 